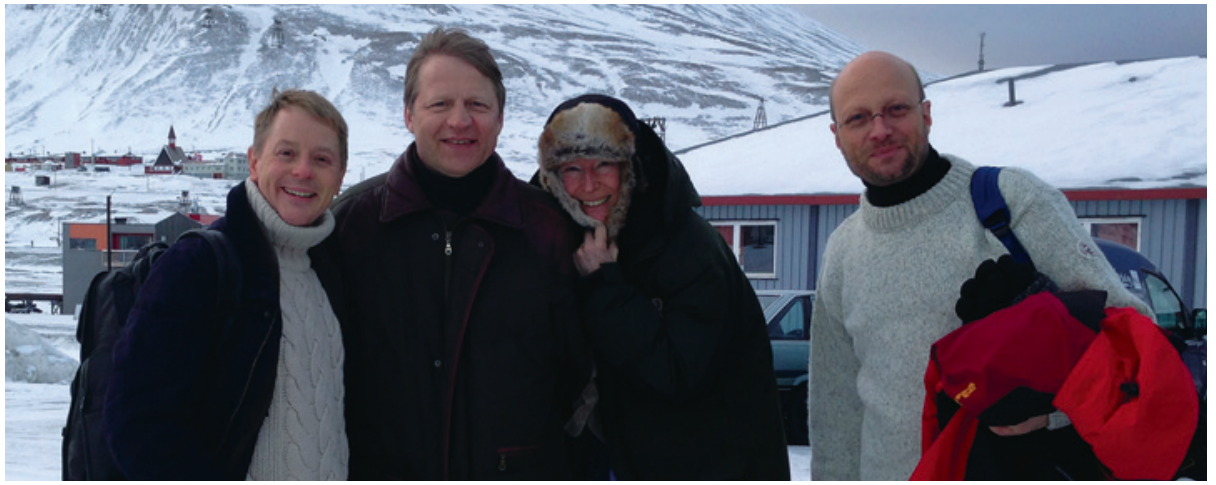

Fra venstre Kevin Sunde Oppegaard, Oskari Heikinheimo, Kristina Gemzell-Danielsson og Christian Fiala. Erik Qvigstad og Lina Benson var ikke til stede da bildet ble tatt. Foto: Privat
Ordforklaringer

Hjemmeabort: Kvinnen tar antiprogesteron [«abortpillen»] under poliklinisk konsultasjon Hun fullfører resten av prosedyren hjemme 24-48 timer senere ved å ta prostaglandintabletter. I tillegg får hun smertestillende tabletter

Non-inferiority: Dette vil si at en behandling ikke er underlegen en annen behandling

Semikvantitativ humant choriongonadotropintest: En graviditetstest som kan måle to eller flere nivåer av svangerskapshormonet i en urinprøve (høy- og lavsensitiv), i motsetning til en vanlig graviditetstest, som bare er høysensitiv.

\title{
Enklere oppfølging etter medisinsk abort
}

En ny studie, med forankring i Norge, viser at egenkontroll er like bra som poliklinisk kontroll etter medisinsk abort.

Medisinsk abort ved bruk av mifepriston og prostaglandiner er den vanligste metoden for provosert svangerskapsbrudd i Skandinavia. Tidlig i svangerskapet kan kvinnen utføre det meste av denne prosedyren selv i eget hjem. Det er uklart om kvinner trenger eller ønsker oppfølging på sykehus etter en slik hjemmeabort. Hvis kvinnen er symptomfri, er eneste grunn til kontroll å bekrefte at hun ikke lenger er gravid. Er det nødvendig å bruke sykehusressurser for å få svar på dette?

I en studie som nylig er publisert i The Lancet ble nesten 1000 kvinner i Østerrike, Finland, Sverige og Norge som skulle utføre medisinsk hjemmeabort, randomisert til egenkontroll og telefonisk oppfølging eller poliklinisk kontroll. De som fikk telefonisk oppfølging, gjennomførte selv en semikvantitativ graviditetstest, som måler to nivåer av svangerskapshormonet humant choriongonadotropin (hCG) i urin. En slik test kan bekrefte en vellykket abort innen et kortere tidsintervall enn det en vanlig graviditetstest kan.

Det var ingen signifikante forskjeller i forekomst av komplikasjoner mellom de to gruppene. Kvinnene som utførte egenkontroll var mer fornøyd med behandlingen sammenliknet med kvinnene som møtte til poliklinisk undersøkelse. I gruppen som utførte egenkontroll, var det tre pågående graviditeter som ikke ble fanget opp av testen, mens det var ingen slike tilfeller blant kvinnene som ble kontrollert på poliklinikk. Bare halvparten av kvinnene hadde begynt med prevensjon én måned etter svangerskapsavbruddet.

- Vår studie indikerer at egenkontroll etter hjemmeabort er trygt, og at kvinner er fornøyd med denne oppfølgingen, sier Kevin Sunde Oppegaard, som er artikkelens førsteforfatter. - Verdens helseorganisasjon (WHO) anbefaler forenkling av protokollen for svangerskapsavbrudd for å øke tilgjengeligheten til abort. Dette er spesielt viktig i ressursfattige land, sier han.

- Tre pågående graviditeter etter abort ble ikke fanget opp av graviditetstesten. Denne testen kan derfor ikke anbefales som erstatning for klinisk kontroll før den er forbedret. At så få hadde begynt med prevensjon én måned etter aborten, er bekymringsfullt. Mange kvinner er ikke klar over at de kan bli gravide igjen etter en abort før neste menstruasjon. Kvinner som søker abort, trenger grundig prevensjonsveiledning og må informeres om at ingen behandling er hundre prosent effektiv og at ingen test er hundre prosent sikker, understreker Oppegaard.

\section{Internasjonalt samarbeid om abortforskning}

Kevin Sunde Oppegaard er gynekolog i Hammerfest og har ledet forskergruppen, som består av flere internasjonale eksperter i feltet. I tillegg til Oppegaard har Erik Qvigstad fra Oslo universitetssykehus bidratt fra Norge. Kristina Gemzell-Danielsson ved Karolinska institutet i Stockholm er direktør for WHO-senteret for forskning i reproduksjonshelse og en av verdens fremste eksperter på svangerskapsavbrudd. Fra Finland og Østerrike deltok henholdsvis Oskari Heikinheimo og Christian Fiala. De statistiske analysene ble gjennomført av Lina Benson, som er statistiker ved Karolinska institutet.

\section{Lise Mørkved Helsingen}

Tidsskriftet

\section{Litteratur}

1. Oppegaard KS, Qvigstad E, Fiala C et al. Clinical follow-up compared with self-assessment of outcome after medical abortion: a multicentre, noninferiority, randomised, controlled trial. Lancet 2014. E-publisert 30.10

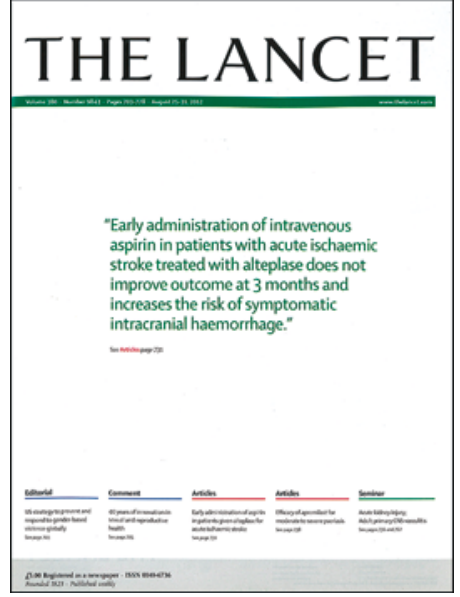

Studien ble publisert i prestisjetunge The Lancet 30.10. 2014 